\title{
The horned crag-and-tails of the Ungava Bay landform swarm, Quebec-Labrador, Canada
}

\author{
Krister N. Jansson, Johan Kleman \\ Department of Physical Geography, Stockholm University, S-106 91 Stockholm, Sweden
}

\begin{abstract}
Till lineations are widespread throughout the interior of Quebec-Labrador, Canada. We discuss a previously unrecognized lineation type, horned crag-andtails, characterized by two till ridges at the lateral flanks of a bedrock crag. This lineation type appears to occur exclusively in the Ungava Bay lineation swarm and has not been reported from other glaciated shield areas. The morphology and spatial distribution of these peculiar landforms are analyzed in the context of Laurentide ice sheet dynamics in central Quebec-Labrador. We propose that a horned crag-and-tail ridge forms when the ice sheet is frozen to the summit of the crag, but basal melting occurs lower down on the crag. The lack of basal sliding at the summit of the crag inhibits till transport across the crag and prevents the accumulation of till in a direct lee-side position. The last phase of the formation is fossilization by basal freezing of the horned crag-and-tail system. This scenario requires that the ice sheet undergoes a transition from frozen-bed conditions to basal melting with frozen patches on topographical highs, and back to fully frozen-bed conditions. Horned crag-and-tails may thus indicate a unique sequence of basal thermal conditions over large areas of Quebec-Labrador.
\end{abstract}

\section{INTRODUGTION}

We report here on a subglacial landform, horned crag-andtail (Figs 1 and 2), characterized by two parallel ridges at the lateral flanks of a bedrock crag. This landform type is morphologically distinct and unique in that it only appears in one specific lineation swarm, in contrast to other subglacial lineations with ubiquitous occurrence, such as flutings, drumlins and conventional crag-and-tails. Horned cragand-tails appear to occur exclusively in the Ungava Bay landform swarm, and cover an area of approximately $30000 \mathrm{~km}^{2}$. They coexist with all classical lineation types in this area. They have not been reported from the other main flow-trace systems in Quebec-Labrador, Canada. During overview mapping from aerial photographs (several million square kilometres evenly distributed over the entire shield areas), we found no similar landforms in any other part of the Laurentide ice sheet area, nor in Fennoscandia. The horned crag-and-tails are important because their more complex morphology, when compared to conventional crag-and-tails, may give important clues to landform-shaping subglacial processes. If their genesis can be understood, they may also provide additional information about the history of the lineation swarm to which their occurrence seems to be restricted, the Ungava Bay landform swarm. The interpretations of the Ungava Bay swarm range from it being young and reflecting late Wisconsinan deglaciation (Prest, 1970; Dyke and Prest, 1987; Boulton and Clark, 1990), to it being a relict feature probably preserved in a frozen-bed zone during the late Wisconsinan (Kleman and others, 1994).

Here we address two crucial questions: (1) under which glaciological conditions did the horned crag-and-tails form? and; (2) why do they only exist in the Ungava Bay landform swarm? The detailed morphology of this particular landform type is described and analyzed, and a genetic model proposed.

\section{PHYSIOGRAPHY}

The study area can be subdivided into five physiographical subdivisions (Fig. 3), the Larch Plateau, Lake Plateau, Caniapiscau Plateau, Labrador Hills and Whale Lowland. Horned crag-and-tails occur on the Caniapiscau, Larch and Lake Plateaus. Larch Plateau is dominated by an undulating surface around $600 \mathrm{~m}$ a.s.l. in the areas between Caniapiscau, Sérigny, and Pons River (Fig. 1), and down to $400 \mathrm{~m}$ a.s.l. in the northern part of the study area. The Archean bedrock is widely exposed and drift is thin over most of its surface (Bostock, 1970). Lake Plateau has been described as a rolling plain with numerous lakes (Hare, 1959), with elevations of 400 to $700 \mathrm{~m}$ a.s.l. The bedrock is composed mainly of Archean granites and granitic gneisses. Today, Larch Plateau is dominated by the Caniapiscau Reservoir at about 535 m a.s.l. Caniapiscau Plateau (Bostock, 1970) or Caniapiscau Upland is characterized by massive, rounded rocky hills (Greene, 1974) where fracture systems are conspicuously etched (Bostock, 1970). The main fracture systems trend southeast-northwest and southwest-northeast. Summits around the Caniapiscau River reach $680 \mathrm{~m}$ a.s.l. and the floor levels of the lowest valleys in the north are around $300 \mathrm{~m}$ a.s.l.

\section{METHODS AND DATA}

The glacial geomorphology was mapped by interpretation of aerial photographs at a scale of 1:60 000. The ice-flow systems in Figure 1 are defined by coherent landform sys- 


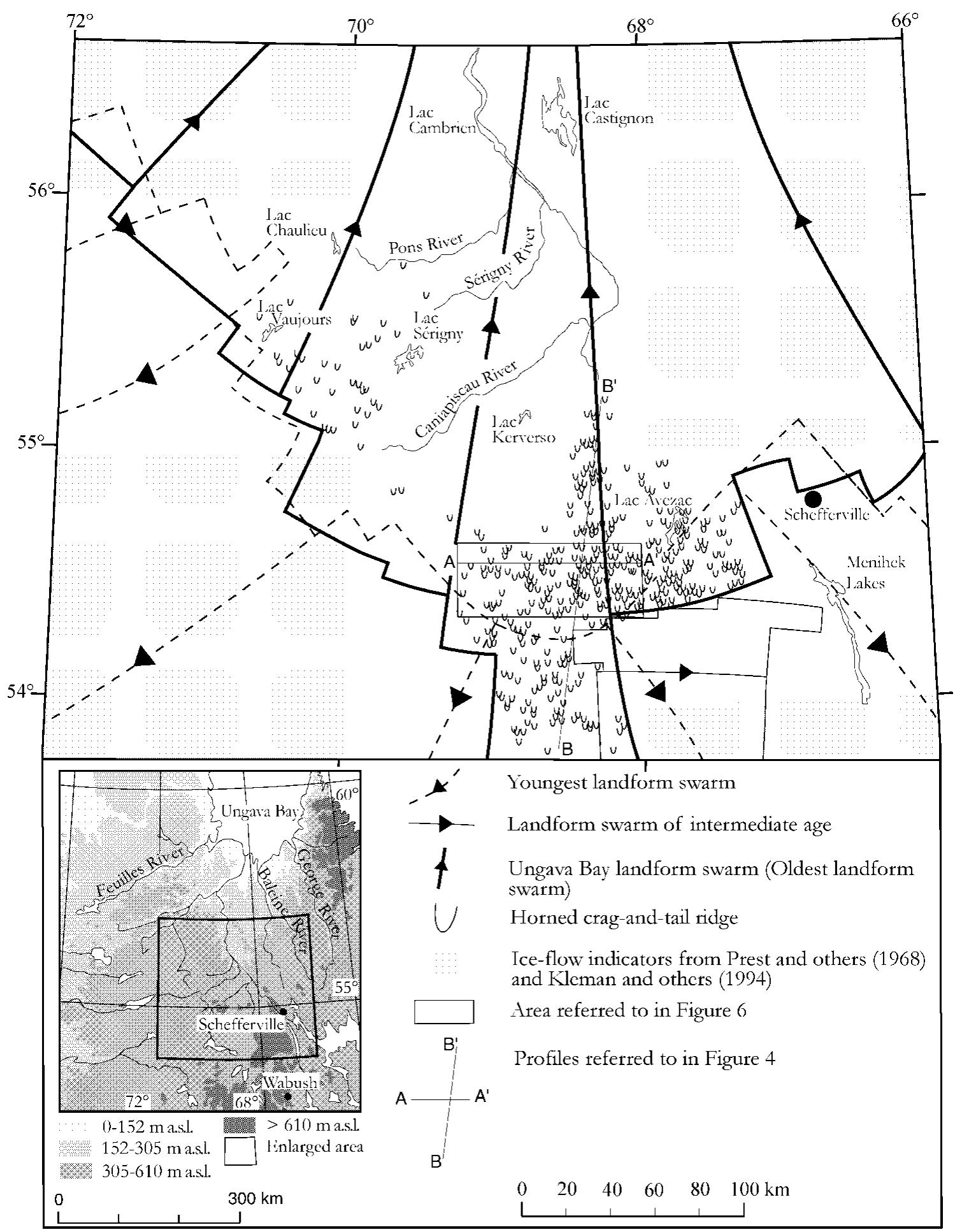

Fig. 1. Geographical distribution of horned crag-and-tails in relation to three of the main ice-flow systems in central QuebecLabrador. Grey-coloured areas show where ice-flow indicators from Prest and others (1968) and Kleman and others (1994) were used for delimiting the ice-flow systems.

tems, mainly composed of till lineations. The outline of iceflow systems outside the mapped area is based on data from Prest and others (1968) and Kleman and others (1994).

The height of individual horned crag-and-tails was measured by a stereomicrometer. Topographical profiles were constructed over the area with the highest density of horned crag-and-tails (Fig. 1). The profiles were constructed from topographical maps at a scale of 1:250 000 and include crag-and-tails and horned crag-and-tails in $7.5 \mathrm{~km}$ wide bands on each side of the profiles. Air reconnaissance of some horned crag-and-tails was carried out about $200 \mathrm{~km}$ northwest of Wabush, Labrador in conjunction with detailed glacial-geological field mapping in 1997.

\section{RESULTS}

\section{Morphological characteristics}

The horned crag-and-tails exhibit a range of morphological variation (Fig. 2), from extremely immature features with poorly developed horns of low relief to well-developed horned crag-and-tails with several kilometre-long tails at the lateral 


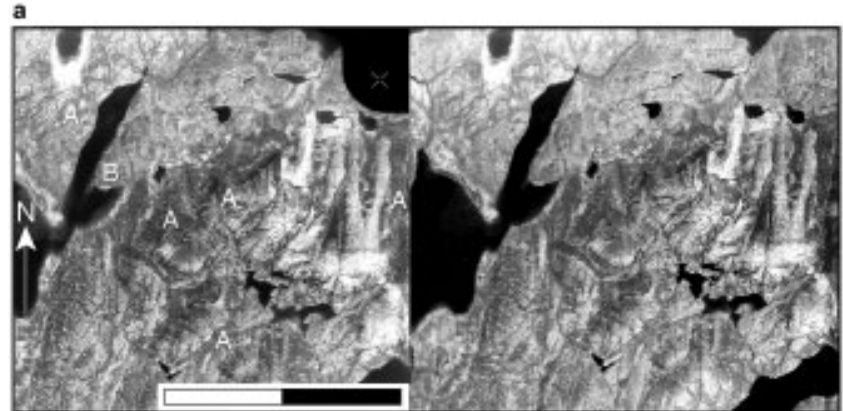

b

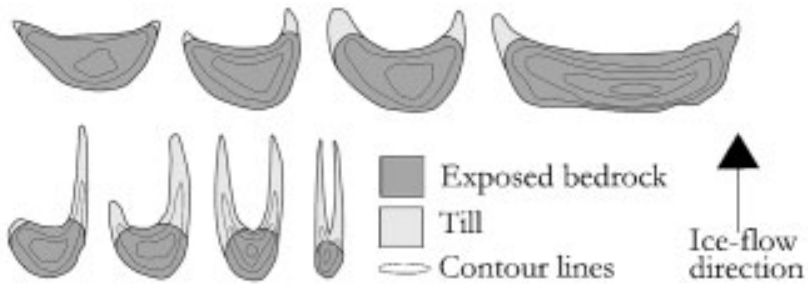

Fig. 2. (a) Stereogram showing horned crag-and-tail ridge varieties $(A)$ and small-scale glacial lineations and drumlins (B) $75 \mathrm{~km}$ west of the northern part of Menihek Lakes. Scale bar is $2 \mathrm{~km}$. (b) A schematic outline of the horned crag-andtails that exhibit a range of morphological variation, from extremely immature features with poorly developed horns of low relief to well-developed horned crag-and-tails with tails several kilometres long at the lateral flanks. A depression in the direct lee-side position of the crag is the common morphological feature.

flanks. Till tails from the lateral flanks down-glacier from a bedrock crag and a depression in the direct lee-side position of the crag are the common morphological features. The leeside depression down-glacier from the bedrock crag varies with the size of the hill. The forms range from those with perfect bilateral symmetry, to those where one horn is much longer and better developed than the other. In some cases, the topography of the horns is extremely subdued, so they are little more than boulder veils traceable to the lateral flanks of a bedrock crag. The average relief of the horned crag-and-tails is approximately $70 \mathrm{~m}$. Maximum and minimum relief are $240 \mathrm{~m}$ and $20 \mathrm{~m}$, respectively.

The vegetation, texture and colour of the tails, seen in aerial photographs and during air reconnaissance, are similar to the surrounding surfaces of drumlins and conventional crag-and-tails. This indicates that the tails consist of till. This is in agreement with the interpretation of Henderson (1956), who during a ground survey in the Lac Avezac area found till thicknesses as great as $15 \mathrm{~m}$ in the drift tails. He found these deposits were identical to drift in conventional crag-and-tails north of the Lac Avezac area. The hollow separating the two tails of the horned crag-and-tails was interpreted as nivation hollows, formed by solifluction and sliding.

\section{Geographical distribution}

The greatest abundance of horned crag-and-tails is southwest of Schefferville, near the proximal end of the Ungava Bay swarm. A second concentration is found near Lac Vaujours and Lac Sérigny (Fig. 1). The frequency of horned crag-and-tails decreases northwards, towards the central and distal part of the Ungava Bay swarm. To the west of Menihek Lakes, there is an abrupt west-east trending boundary, south of which no horned crag-and-tails are found. This

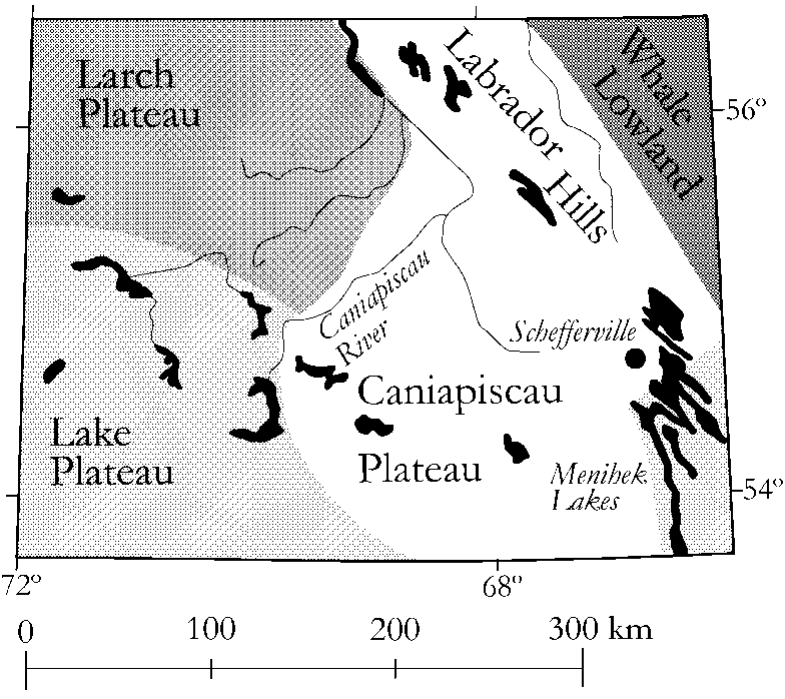

Fig. 3. The five physiographical subdivisions of the study area (redrawn from Bostock, 1970).

boundary seems to be a result of headward propagation of, and erosion by, a younger lineation swarm indicating ice flow towards the east (flow event IV in Klassen and Thompson, 1993; fan D in Kleman and others, 1994). At the southwestern limit of the Ungava Bay swarm, it is difficult to determine if the present southwestern limit of horned crag-andtails reflects a primary formational limit, or is the result of erosion by the youngest radial flow from a dispersal centre presumed to be over or north of Lac Cambrien and Lac Castignon (Fig. 1).

\section{Topographical distribution}

Figure 4 shows the vertical distribution of horned crag-andtails and conventional crag-and-tails. Although there is some overlap between the groups, the difference in vertical distribution is distinct, with horned crag-and-tails occurring at higher elevations than conventional crag-and-tails. This distribution pattern exists at both regional and local scales. The conventional crag-and-tails are almost completely replaced by horned crag-and-tails on the extreme highpoints in the terrain.

\section{MODE OF FORMATION}

The horned crag-and-tails are always oriented parallel to surrounding conventional till lineations (drumlins, fluting, crag-and-tails) belonging to the Ungava Bay landform swarm (Fig. 1), and show a distinctly different vertical distribution when compared to conventional crag-and-tails. A subglacial formation of the horned crag-and-tails appears clear and the directional agreement to intervening drumlins and conventional crag-and-tails suggests they formed at the same time as the other lineation features in the Ungava Bay landform swarm. This is in conflict with an earlier interpretation of these features as postglacial nivation hollows (Henderson, 1956).

Processes such as subglacial lodgement (Fairchild, 1907; Boulton, 1982), deformation of a deforming till layer (Smalley and Unwin, 1968; Menzies, 1979; Boulton, 1987; Hart, 1997) and meltout of basal debris-rich ice (Shaw, 1980) have been suggested for drumlin formation. These theories address the mode of deposition and shaping of drumlins, and by inference 


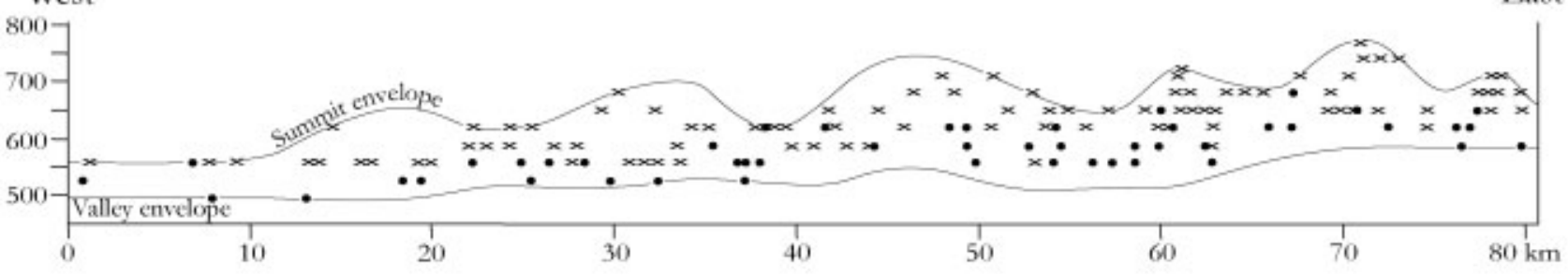

B

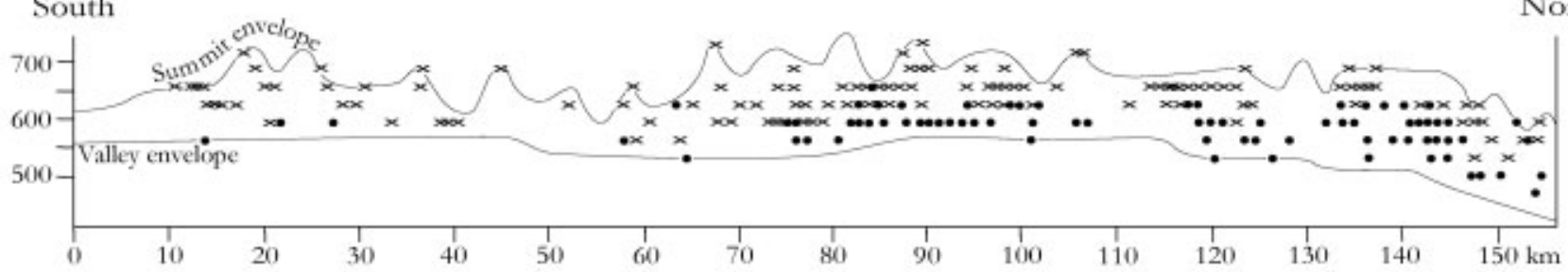

Summit envelope, shows the highest summits along the transect.

Valley envelope, shows the elevation of the valleyfloors along the transects

× Horned crag-and-tail

- Convential crag-and-tail

Fig. 4. Vertical distribution of horned crag-and-tails and conventional crag-and-tails projected onto the two $15 \mathrm{~km}$ wide transects $A$ and B (see Fig 1).

also the tails of conventional crag-and-tails (the crags assumed to be inherited irregularities of the bedrock surface). It is also conceivable that drumlins may in some cases form predominantly by erosion of an originally smooth, pre-existing drift sheet (Whittecar and Mickelson, 1977). Regardless of the precise mode of formation, it can safely be stated that most composite rock/drift lineations in formerly glaciated areas are of the conventional crag-and-tail type, i.e. the drift is only present in a direct lee-side position in relation to the tail.

Differences in morphology and topographical distribution between horned crag-and-tails and conventional cragand-tails and the concentration to one specific lineation system seems to indicate that a traditional crag-and-tail formation hypothesis is not sufficient. In our opinion, any formation hypothesis should be able to explain the following characteristics: (1) that the tails begin appreciably lower than the summit of the crag; (2) the lack of deposits directly in the lee of the crag; (3) the difference in topographical distribution between horned crag-and-tails and conventional crag-and-tails; and (4) their restriction to north-central Quebec-Labrador and the Ungava Bay landform swarm.

Boulton (1987) suggested accumulation by deforming sediment around a more-resistant mass for the barchan-like drumlins in Northern Ireland (cf. Dardis and others, 1984) and that those landforms reflect a sediment starvation, where relatively little deforming sediment moves over the summit and around the flanks of the core. However, the very specific distribution pattern, both on the local and regional scale, suggests that it is unlikely that a general characteristic such as ice velocity or a relative lack of basal debris can credibly explain the horned crag-and-tails.

We search instead for conditions, or chains of events, that could induce abrupt erosion-transport-deposition boundaries at hill-sized obstacles. A secondary requisite is that the appropriate conditions would have to favour horned crag- and-tail development at higher elevations, but the formation of conventional crag-and-tails at lower elevations.

The lack of sediment immediately behind the crag, which is the hallmark of the landform type, can result from either: (a) much more efficient removal (entrainment) of debris from this position; or (b) inhibited transport of material into the direct lee position.

Therefore, we look for mechanisms or chains of events that would allow (a) or (b) to happen. An additional requisite is that they should not be commonplace, or else these landforms would not be restricted to one particular lineation swarm. Basal melting on the upstream side of the crag, and entrainment and removal of debris by refreezing in the lee of the crag could potentially explain the lack of lee-side deposit. But being a local mechanism related to each individual crag, it fails to explain the selective topographical distribution of horned crag-and-tails. We therefore favor an explanation of type (b), inhibited transport of material into the direct lee-side position.

The affinity of the horned crag-and-tails to topographical highs and conventional crag-and-tails to low points, and the lack of deposits behind crags which is inferred to be a result of inhibited till transport across the summits, suggests that a frozen bed at the summit may be involved. The fact that they are apparently restricted to only one lineation swarm, but lacking in all others, may indicate they did not form under steady-state conditions, but rather are the result of one particular chain of subglacial events. We suggest the following sequence of events (Fig. 5), where the first stage in formation is the existence of a non-erosive ice sheet (Fig. 5a) with fully frozen-bed conditions. This is suggested because an ice sheet with a fully thawed bed will probably form conventional crag-and-tails, instead of horned crag-and-tails. We envisage a transformation to wet-bed conditions at subglacial low points and frozen patches at higher elevations (Fig. 5b). These basal conditions obstruct till transport 


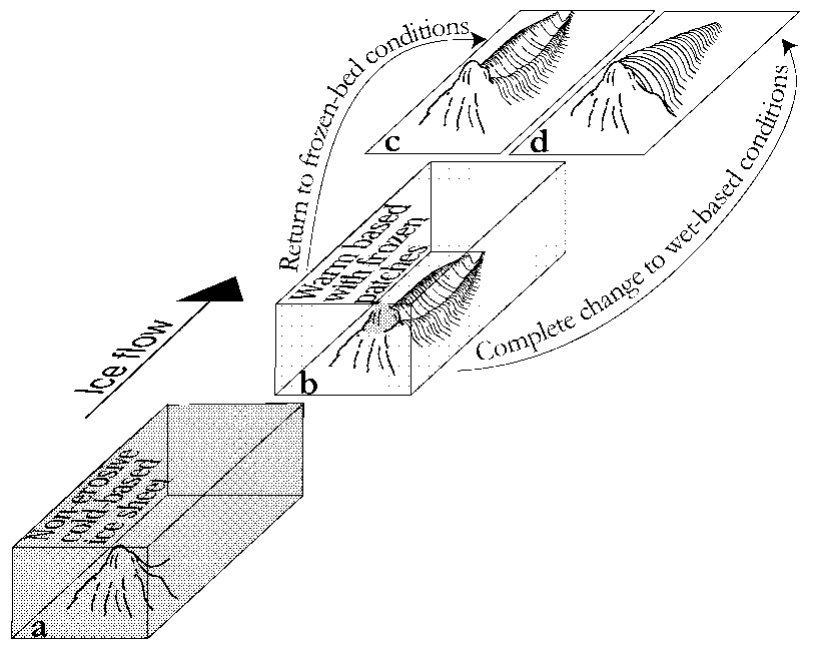

Fig. 5. Model of horned crag-and-tail ridge formation, showing the successive transformation of subglacial conditions during which these features were formed. (a) The existence of non-erosive cold-based ice is crucial to avoiding formation of conventional crag-and-tails during this stage of ice-sheet coverage. (b) The basal temperature distribution underwent a transformation from fully frozen-bed conditions to frozen only on summits. These basal conditions with thawed bed at low points and frozen patches at higher elevation prevents till transport across the cold-based bedrock crag. Such a smallscale basal zonation allows till transport during wet-based conditions along the lower shoulders of the crag and accumulation in two tails at the lateral flanks. (c) The end result after a fully frozen deglaciation. These basal conditions preserve the entire horned crag-and-tail ridge system. (d) A transition from warm-based with cold patches on summits to a thawed-bed deglaciation This prevents the preservation of the horned crag-and-tail system and instead leads to infilling of the depression between the two tails.

across the cold-based bedrock crag and thereby prevent accumulation at a direct lee-side position of the crag. Such a small-scale basal zonation allows till transport during wetbased conditions along the lower shoulders of the crag and accumulation in two tails at the lateral flanks.

The last phase of the formation of a horned crag-and-tail ridge is by basal freezing of the horned crag-and-tail ridge system and preservation throughout a fully frozen-bed deglaciation (Fig. 5c). This suggested scenario requires that the ice sheet undergoes a transition from frozen-bed conditions to basal melting with frozen patches and back to frozen-bed conditions. If this is not the case, formation of conventional crag-and-tails will occur (Fig. 5d).

The difference in vertical distribution may indicate that horned crag-and-tails are immature crag-and-tails, i.e. that after some time of fully thawed-bed conditions, all horned crag-and-tails would evolve into conventional crag-and-tails.

Horned crag-and-tails may develop during a chain of changes in basal conditions, with a period of patchy frozenthawed-bed conditions being an important ingredient. Figure 6 visualizes the occurrences of horned crag-and-tails in their topographical context. It shows how a smoothed undulating surface, approximately delimiting the lower limit of horned crag-and-tails, intersects the terrain. The topography in an area north of Lac Rousson (Fig. 1) was digitized from 1:250000 scale maps, with a contour interval of $\sim 30.5 \mathrm{~m}$
$(100 \mathrm{ft})$. The area includes profile $\mathrm{A}-\mathrm{A}^{\prime}$ and parts of profile B-B' (Fig. 1) and has a relative relief of about $150 \mathrm{~m}$. The digitized data were used to construct a surface map with a gridline spacing of $0.3 \mathrm{~km}$. Kriging was used as the gridding method. The next step was to assign $x, y$ and $z$ values to mapped horned crag-and-tails. To account for the fact that horns adjacent to the larger crags, which typically reach higher absolute elevations, occur well below the crag summits, the $z$ values of individual crags $=610 \mathrm{~m}$ a.s.l. were lowered by $40 \mathrm{~m}$, $z$ values $<610-579 \mathrm{~m}$ a.s.l. were lowered by $20 \mathrm{~m}$, and $z$ values $<579 \mathrm{~m}$ were not corrected. The smoothed surface describing the elevations of the horned crag-and-tails was subtracted from the topographical surface map. The result is a contour map where the negative values are coloured grey and the positive white, which was superimposed on the gridded surface map and indicates land above and below the smoothed surface. Areas above this smoothed surface are shown in white and terrain below it in grey. Based on the inference that the horned crag-and-tails form because frozenbed conditions inhibit debris transport across topographical highs, we suggest that the white areas in Figure 6 approximate the frozen-bed areas during formation of the horned crag-and-tails. Similar frozen-thawed-bed patchworks in low-relief terrain have been described from northern Sweden by Kleman and Borgström (1990, 1994) and Clarhäll and Kleman (1999).

\section{IMPLICATIONS FOR ICE-SHEET DYNAMICS DUR- ING AND AFTER FORMATION OF THE HORNED GRAG-AND-TAILS AND THE UNGAVA BAY LAND- FORM SWARM}

The horned crag-and-tails appear to be unique to one particular flow-trace swarm and, according to the formation hypothesis discussed, did not form under steady-state conditions, but instead required a specific chain of subglacial events for their formation.

The landform swarm in which the horned crag-and-tails occur is strongly convergent. In view of the above formation hypothesis, we suggest that it was fully wet-based in the central and distal (northern) parts, whereas the southern part, where the horned crag-and-tails occur only briefly, experienced some wet-bed conditions before refreezing. The dispersal centre during formation was to the south of the occurrence area of horned crag-and-tails and, in view of recent work suggesting frozen-bed core areas to be a normal features of mid-latitude ice sheets (Sollid and Sørbel, 1988; Huybrechts and T'siobbell, 1995; Kleman and others, 1997), it appears likely they formed in a transition zone between frozen and thawed bed. This is unlikely to have been a stable position of a subglacial boundary, because there are indications that the Ungava Bay swarm represents one or more rapid-flow events (Clark, 1999).

The horned crag-and-tails suggest that at least the southern part of the Ungava Bay swarm formed as the result of a brief period of partial basal thawing and rapid flow, followed by refreezing of the bed. This is in line with the scenario suggested by Clark (1999) for the glacial dynamics of the Labrador sector of the Laurentide ice sheet.

The existence of horned crag-and-tails in the Ungava Bay landform swarm may indicate unique conditions during formation, but more probably a unique chain of changes in basal conditions during a long period of glacerization in 


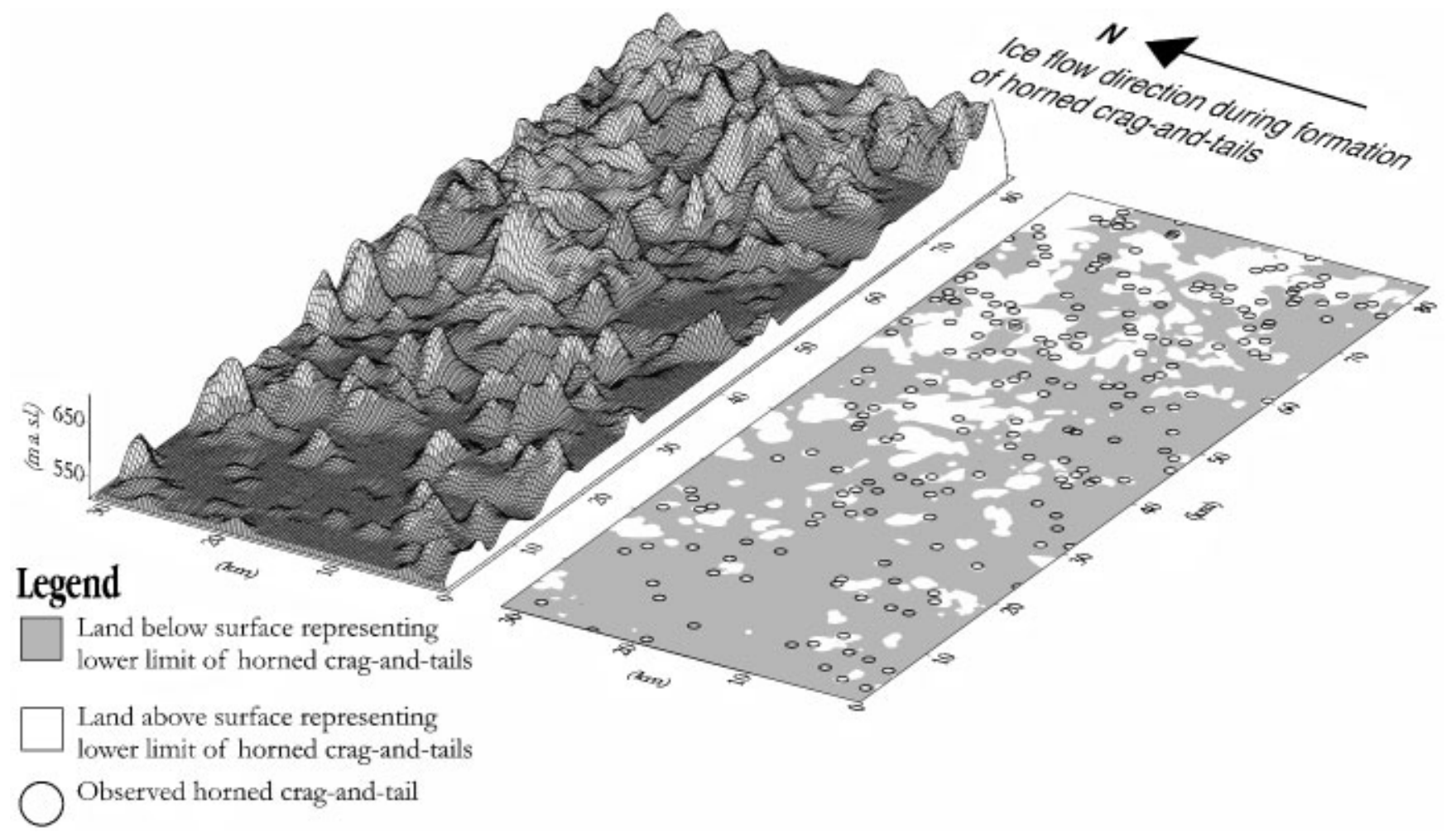

Fig. 6. Visualization of horned crag-and-tails in their topographical context. It shows a smoothed surface approximately delimiting the lower limit of horned crag-and-tails. We infer that the white areas approximate the frozen-bed areas during formation of the horned crag-and-tails.

north-central Quebec-Labrador. The terrain in the area is not unusual, but the moderate relief with solitary hills may have been an important factor in favouring a small-scale frozen-thawed-bed patchwork.

The lack of eskers, the well-ordered suites of marginal meltwater channels (Kleman and others, 1994) and the lack of subglacial lineations matching the retreat pattern indicated by the meltwater landforms, suggest that final deglaciation of the study area occurred under frozen-bed conditions, conducive to the preservation of the Ungava Bay landform swarm. However, the intervening glacial history (between formation of the Ungava Bay swarm and final deglaciation) is debatable and poorly constrained, and a better understanding of the glaciodynamic context of these peculiar landforms must probably await a better understanding of the complex flow-pattern evolution in the area.

\section{GONGLUSIONS}

Horned crag-and-tails are a morphologically distinct member of the glacial lineation family. They are characterized by two flow-aligned till ridges emanating from the lateral extremities of a bedrock crag.

Horned crag-and-tails are only known from one glacial lineation swarm, the Ungava Bay landform swarm, where they occur in abundance in the proximal part of the swarm.

The present geographical distribution of horned crag-andtails is thought to be partly a function of younger glacial erosion.

We suggest that the horned crag-and-tails formed as the result of a sequence of subglacial events involving partial thawing of the bed and preservation resulting from refreezing.

\section{AGKNOWLEDGEMENTS}

This study was funded by the Swedish National Science Research Council. Additional funding was also given by the Swedish Society of Anthropology and Geography, the Margit Ahltins fund of the Royal Swedish Academy of Sciences, and the Mannerfelts, Axel Lagrelius and Hans $\mathrm{W}$ :son Ahlmanns funds. These institutions are greatly acknowledged for their financial support. We also want to thank C. Hättestrand and A. P. Stroeven for constructive discussions and comments on the manuscript. Referees comments from C. D. Clark and B. R. Rea improved the paper.

\section{REFERENGES}

Bostock, H. S. 1970. Physiographic subdivisions of Canada. Geol. Surv. Can. Econ. Geol. Rep. 1, 9-30.

Boulton, G. S. 1982. Subglacial processes and the development of glacial bedforms. In Davidson-Arnott, R., W. Nickling and B. D. Fahey, eds. Research in glacial, glacio-fluvial and glacio-lacustrine systems. Norwich, Geo Books (Geo Abstracts Ltd), 1-31. (Geographical Publication 6.)

Boulton, G. S. 1987. A theory of drumlin formation by subglacial sediment deformation. In Menzies, J. and J. Rose, eds. Drumlin Symposium. Rotterdam, A.A. Balkema, 25-80.

Boulton, G. S. and C. D. Clark. 1990. A highly mobile Laurentide ice sheet revealed by satellite images of glacial lineations. Nature, 346(6287), 813-817.

Clarhäll, A. and J. Kleman. 1999. Distribution and glaciological implications of relict surfaces on the Ultevis Plateau, northwestern Sweden. Ann. Glaciol., 28 (see paper in this volume).

Clark, C. D. 1999. Glaciodynamic context of subglacial bedform generation and preservation. Ann. Glaciol., 28 (see paper in this volume).

Dardis, G. F., A. M. McCabe and W. I. Mitchell. 1984. Characteristics and origins of lee-side stratification sequences in Late Pleistocene drumlins, northern Ireland. Earth Surf. Processes Landforms, 9(5), 409-424.

Dyke, A. S. and V. K. Prest. 1987. Late Wisconsinan and Holocene history of the Laurentide ice sheet. Géogr. Phys. Quat., 41 (2), 237-263.

Fairchild, H. L. 1907. Drumlins of central western New York. N.Y. State Mus. Bull. 111, 391-443.

Greene, B. A. 1974. An outline of the geology of Labrador, Newfoundland. St. John's, 
Nfld, Government of Newfoundland and Labrador. Department of Mines and Energy. Mineral Development Division. (Report 15.)

Hare, F. K. 1959. Mapping of physiography and vegetation in LabradorUngava. Can. Geogr., 5, 17-28.

Hart, J. K. 1997. The relationship between drumlins and other forms of subglacial glaciotectonic deformation. Quat. Sci. Rev., 16(1), 93-107.

Henderson, E. P. 1956. Large nivation hollows near Knob Lake, Quebec. F. Geol., 64(6), 607-616.

Huybrechts, P. and S. T'siobbel. 1995. Thermomechanical modelling of Northern Hemisphere ice sheets with a two-level mass-balance parameterization. Ann. Glaciol., 21, 111-116.

Klassen, R.A. and F.J. Thompson. 1993. Glacial history, drift composition, and mineral exploration, central Labrador. Geol. Surv. Can. Bull. 435.

Kleman, J. and I. Borgström. 1990. The boulder fields of Mt. Fulufjället, west-central Sweden - Late Weichselian boulder blankets and interstadial periglacial phenomena. Geogr. Ann., 72A (1), 63-78.

Kleman, J. and I. Borgström. 1994. Glacial land forms indicative of a partly frozen bed. F. Glaciol., 40(135), 255-264.

Kleman, J., I. Borgström and C. Hättestrand. 1994. Evidence for a relict glacial landscape in Quebec-Labrador. Palaeogeogr., Palaeoclimatol., Pa- laeoecol., 111 (3-4), 217-228.

Kleman, J., C. Hättestrand, I. Borgström and A. Stroeven. 1997. Fennoscandian palaeoglaciology reconstructed using a glacial geological inversion model. F. Glaciol., 43(144), 283-299.

Prest, V. K. 1970. Quaternary geology of Canada. Geol. Surv. Can. Econ. Geol. Rep. 1, 675-765.

Prest, V. K., D. R. Grant and V. N. Rampton. 1968. Glacial map of Canada. Ottawa, Ont., Geological Survey of Canada. (GSC Map 1253A, scale $1: 5,000,000$.)

Shaw, J. 1980. Drumlins and large-scale flutings related to glacier folds. Arct. Alp. Res., 12(3), 287-298.

Smalley, I.J. and D.J. Unwin. 1968. The formation and shape of drumlins and their distribution and orientation in drumlin fields. F. Glaciol., $\mathbf{7}(51), 377-390$

Sollid, J. L. and L. Sörbel. 1988. Influence of temperature conditions in formation of end moraines in Fennoscandia and Svalbard. Boreas, $17(4)$, 553-558.

Whittecar, G. R. and D. M. Mickelson. 1977. Sequence of till deposition and erosion in drumlins. Boreas, $6(2), 213-217$. 